\title{
Auditor Performance in Public Accounting Firm in Riau: The Moderating Effect of Emotional Quotient
}

\author{
Meilda Wiguna, Khoirul Aswar, and Eka Hariyani
}

\begin{abstract}
This study aims to examine the effect of role conflict, role ambiguity, self-efficacy, and spiritual quotient on auditor performance with emotional quotient as a moderating variable. The sample of this study was 45 auditors from 15 public accounting firms in Riau and Riau Islands. The analytical method in this study is multiple regression analysis and Moderated Regression Analysis (MRA). The results showed that (1) Role Conflict negatively affected Auditor Performance (2) role ambiguity negatively affected auditor performance (3) selfefficacy had a positive effect on auditor performance (4) spiritual quotient had no effect on auditor performance (5) emotional quotient has moderates the relationship between role conflict, role ambiguity, self-efficacy, and spiritual quotient with auditor performance.
\end{abstract}

Keywords-Aauditor performance, Role conflict, Role ambiguity, Self efficacy, Spiritual quotient, Emotional quotient.

\section{INTRODUCTION}

The performance of a public accounting firm is largely determined by the conditions and behavior of the auditors at the public accounting firm. When an auditor has done his job well, it will have an impact on a good track record of performance for the auditor and the Public Accounting Firm. According to Kalbers and Fogarty (1995), performance is the result of work that has been achieved by someone in carrying out their assignments in accordance with the responsibilities given.

Auditor performance is very required so the cases that have happened in Indonesia, namely the case at SNP Finance Corporation, do not recur. The case was about breaking into 14 bank credit with a loss of Rp14 trillion. The Ministry of Finance, in this case, the Center for Financial Professional Development (PPPK) conducted an analysis of the subject matter and concluded that there were indications of violations of professional standards in audits conducted by the Public Accountant in conducting a general audit of SNP Finance Corporation's financial statements for fiscal years 2012 to 2016. So the Minister of Finance of the Republic of Indonesia imposed administrative sanctions on several public accounting firms that was involved in the case (www.pppk.kemenkeu.go.id).

Published on February 21, 2020

Meilda Wiguna, Economics and Business Faculty Universitas Riau, Indonesia.

(e-mail: meildawiguna@yahoo.com)

Khoirul Aswa, Economics and Business Faculty Universitas Pembangunan Nasional Veteran Jakarta, Indonesia.

(e-mail: aswar law@yahoo.com)

Eka Hariyani, Economics and Business Faculty Universitas Riau, Indonesia.

(e-mail: e.honey85@yahoo.com)
There are several factors that affect the performance of the Auditor. The first factor is the Role Conflict. According to Hanna and Firnanti (2013), role conflict is a form of incompatibility between bureaucratic control mechanisms, norms, rules, ethics, and independence from professionals. Sometimes this role conflict can occur due to two or more different work demands, making it difficult for auditors to carry out their roles.

Role conflict is not the only factor that can make it difficult for auditors. Role Ambiguity, as a second factor, can also make it difficult for auditors to carry out audits so their performance could be decreases. Agustina (2009) states that role ambiguity refers to a lack of clarity regarding job expectations, methods for meeting known expectations and/or consequences of certain performance or roles.

The third factor that affects auditor performance is Selfefficacy. According to Bandura (1991), self-efficacy is a belief in one's ability to carry out some assignments. People who are confident in their abilities tend to succeed, whereas people who always feel like fail tend to fail.

The fourth factor is the Spiritual Quotient (spiritual intelligence). Spiritual intelligence is the intelligence to face and solve problems regarding meaning and value. It means placing human behaviour and life in the context of a broader and richer meaning, and assessing one's actions or way of life is more meaningful than others (Choiriah, 2013).

Furthermore, in this study, there is a moderation factor, namely Emotional Quotient (emotional intelligence). Emotional intelligence according to Goleman (1999) is the ability that includes self-control, enthusiasm, and perseverance, as well as the ability to be self-motivated, resilience in the face of failure, controlling emotions and delay satisfaction, and regulate the mental condition.

\section{LiteratURE REVIEW}

\section{A. Effect of Role Conflict on Auditor Performance}

There is an asynchrony between the demand or expectation of the job with the commitment of the role being carried out. Role conflict arises in different ways that are carried out by different people, causing different priorities and lead to unclear orders. Auditor performance is an realization of work performed in order to achieve better or prominent work results towards the achievement of organizational goals (Fanani et al, 2008).

When an auditor carries out his audit work, often the auditor receives two opposite orders (intra role conflict) and works in two opposite roles (inter role conflict). Of course, this will make auditors uncomfortable in carrying out audits that impact on their performance results. Research conducted by Rosally \& Jogi (2015) and Agustina (2009) shows that role conflict has a significant negative effect on auditor performance. This means the higher role conflict, the auditor's performance is also lower. 
Based on a brief description of the theory and the results of previous research, the hypotheses built is:

$\mathrm{H}_{1}$ : Role Conflict affects the Auditor's Performance

\section{B. Effect of Role Ambiguity on Auditor Performance}

Role ambiguity occurs when no information is needed to carry out an assignment or role. Agustina (2009) states that role ambiguity refers to a lack of clarity regarding job expectations, methods for meeting known expectations and/or consequences of certain performance or roles.

Auditor performance is a realization of work performed in order to achieve better or prominent work results towards the achievement of organizational goals (Fanani et al, 2008).

When trying to carry out his work as an auditor, but there is no enough information about what will be done, it is not clear to whom he will be responsible, and also he does not understand what exactly is expected of him. This unclear role will make it difficult for the auditor to carry out his audit so that the auditor's performance will be declined. According to the research of Hanna and Finanti (2013), Arianti (2015), and Fauziah (2018), role ambiguity has a significant negative effect on the auditor. This means that the higher the level of role clarity, the auditor's performance will decrease.

Based on a brief description of the theory and the results of previous research, the hypotheses built is:

$\mathrm{H}_{2}$ : Role Ambiguity affects the Auditor's Performance

\section{Effect of Self-Efficacy on Auditor Performance}

Self-efficacy is defined as the human belief in their ability to practice several measures of control over their selffunction and the events in their environment. Individual beliefs about their abilities are determinants of how individuals act, patterns of thinking, and emotional reactions experienced in certain situations (Bandura, 1997).

According to Kalbers and Fogarty (1995), performance is the result of work achieved by someone in carrying out assignments following the responsibilities given.

The auditor's job is full of challenges. When the auditor believes in carrying out his audit duties, the auditor will know what actions will be taken, confident that it can complete the task well, and be able to win the challenge. In line with research conducted by Wiguna (2014) and Kristiyanti (2015) that there is a positive effect of self-efficacy on auditor performance. Successfully increasing self-confidence (selfefficacy), the better the performance of auditors will be.

Based on a brief description of the theory and the results of previous research, the hypotheses built is:

$\mathrm{H}_{3}$ : Self-Efficacy affects the Auditor's Performance

\section{Effect of Spiritual Quotient on Auditor Performance}

According to Choiriah (2013), an auditor who has adequate spiritual intelligence will be able to synergize the two other intelligence elements they have, so that every work they do will be more meaningful. The meaning that will emerge in an organization will make everyone who works in it more able to develop themselves. The result is they can work better too.

Research conducted by Setiawan (2018) shows that spiritual intelligence has a positive effect on auditor performance. This means that the higher the auditor's spiritual intelligence, his performance will also increase.

Based on a brief description of the theory and the results of previous research, the hypotheses built is:

$\mathrm{H}_{4}$ : Spiritual Quotient affects the Auditor's Performance

\section{E. Emotional Quotient Moderate the Relatioship between Role Conflict, Role Ambiguity, Self-Efficacy, Spiritual Quotient on Auditor Performance}

Emotional intelligence according to Goleman (1999) is the ability that includes self-control, enthusiasm, and perseverance, as well as the ability to be self-motivated, resilience in the face of failure, controlling emotions and delay satisfaction, and regulate the mental condition. With emotional intelligence, a person can place his emotions at the right level, sort out satisfaction and regulate mood. Research conducted by Wiguna (2014), the emotional quotient can moderate the relationship between self-efficacy and auditor performance, but not for the between role conflict and role ambiguity. However, in research conducted by Yustiarti et al (2016), that emotional quotient can moderate the influence of role conflict and role ambiguity.

Based on a brief description of the theory and the results of previous research, the hypotheses built are:

$\mathrm{H}_{5}$ : Emotional Quotient moderate the relationship between Role Conflict and Auditor Performance

$\mathrm{H}_{6}$ : Emotional Quotient moderate the relationship between Role Ambiguity and Auditor Performance

$\mathrm{H}_{7}$ : Emotional Quotient moderate the relationship between Self Efficacy and Auditor Performance

$\mathrm{H}_{8}$ : Emotional Quotient moderate the relationship between Spiritual Quotient and Auditor Performance

\section{Research Methodology}

This study uses a survey method through a questionnaire. Data obtained by distributing questionnaires to respondents of the Public Accountant Firm in Riau region and Riau Island. The type of data used in this study is primary data in the form of a questionnaire, and each variable is measured using Likert 5-point scales, that is scale (1) strongly agree, (2) agree, (3) neutral, (4) disagree, and (5) strongly disagree. The data collected was processed with the help of a computer program, namely SPSS version 20.0.

\section{Results And Discussion}

\section{A. Demographic Respondents}

The researcher distributed 45 questionnaires to 8 public accounting firms in the Riau region and 7 public accounting firms in Riau Islands region. Each public accounting firm gets 3 questionnaires to be filled out by its auditors. From the questionnaire distributed, the whole can be returned and can be processed so that there are as many as 45 questionnaires processed in this study. In the Respondent Characteristics on age, for men it is $67 \%$ while for women it is $33 \%$. The next respondent characteristic is based on the education level, the percentage of bachelor degree is $76 \%$ and $24 \%$ for the master degree. 


\section{B. Results}

The coefficient of determination $\left(\mathrm{R}^{2}\right)$ is used to measure how far the model's ability to explain the variation of the dependent variable. Value in the coefficient of determination range between 0 (zero) and 1 (one). A small value means that the ability of the independent variables to explain the variation of the dependent variable is very limited. A value that close to one means that the independent variables provide almost all the information needed to predict the variation of the dependent variable, (Ghozali, 2013).

Based on the data processing, the results are as follows:

TABLE I: COEFFICIENT OF DETERMINATION TEST

\begin{tabular}{lllllll}
\hline Model & R & $\begin{array}{l}\text { R } \\
\text { Square }\end{array}$ & $\begin{array}{l}\text { Adjusted } \\
\text { Square }\end{array}$ & $\begin{array}{l}\text { Std. Error of } \\
\text { the Estimate }\end{array}$ & $\begin{array}{l}\text { Durbin- } \\
\text { Watson }\end{array}$ \\
\hline 1 & $.743^{\mathrm{a}}$ & .552 & .576 & 2.10290 & 1.735 \\
\hline
\end{tabular}

Based on the table above, it is known that the Rsquare value is 0.552 and the Adjusted $R$ Square value is 0.576 . It means that the contribution of the influence of the independent variable to the dependent variable is $57.6 \%$. While the remaining $42.4 \%$ is influenced by other variables that are not included in this research model.

The results of the hypothesis testing of this study can be seen in Table 2.

TABLE II: TESTING OF HyPOTHESIS OF DESCRIPTIVE STATISTICS

\begin{tabular}{llllll}
\hline Hypothesis & $\mathbf{t}_{\text {count }}$ & $\mathbf{t}_{\text {table }}$ & Sig & $\begin{array}{c}\text { Alpha } \\
(\boldsymbol{\alpha})\end{array}$ & Description \\
\hline $\mathrm{H}_{1}$ & $-5,296$ & 1,684 & 0,000 & 0,05 & Accepted \\
$\mathrm{H}_{2}$ & $-4,305$ & 1,684 & 0,000 & 0,05 & Accepted \\
$\mathrm{H}_{3}$ & 1,723 & 1,684 & 0,020 & 0,05 & Accepted \\
$\mathrm{H}_{4}$ & 0,273 & 1,684 & 0,786 & 0,05 & Rejected \\
$\mathrm{H}_{5}$ & 1,805 & 1,684 & 0,038 & 0,05 & Accepted \\
$\mathrm{H}_{6}$ & 2,067 & 1,684 & 0,047 & 0,05 & Accepted \\
$\mathrm{H}_{7}$ & 3,210 & 1,684 & 0,017 & 0,05 & Accepted \\
$\mathrm{H}_{8}$ & 2,586 & 1,684 & 0,013 & 0,05 & Accepted \\
\hline
\end{tabular}

Based on the Table 2. The Regression test result for hypothesis 1 , obtained $t_{\text {count }}$ of -5.296 and $t_{\text {table }}$ of 1.684 with a significance level of 0.000 , which is less than 0.05 . Based on the results of this study, $\mathrm{H}_{1}$ is accepted, which means that Role Conflict affect Auditor Performance. Role conflict has a communion with auditor performance. Where the high role conflict faced by an auditor, will highly effecting the performance of an auditor. 1

The Regression test result for hypothesis 2 obtained $t_{\text {count }}$ of $-4,305$ and $t_{\text {table }}$ of 1,684 with a significance level of 0.000 , which is less than 0.05 . Based on the results of this study, $\mathrm{H}_{2}$ is accepted, which means that Role Ambiguity affect Auditor Performance. Role ambiguity has a communion with auditor performance. Where the high role ambiguity faced by an auditor, will highly effecting the performance of an auditor.

The Regression test result for hypothesis 3 obtained $t_{\text {count }}$ of 1,723 and $t_{\text {table }}$ of 1,684 with a significance level of 0.020 , which is less than 0.05 . Based on the results of this study, $\mathrm{H}_{3}$ is accepted, which means that Self Efficacy affect Auditor Performance. Self efficacy has a communion with auditor performance. Where the high self efficacy faced by an auditor, will highly effecting the performance of an auditor.
The Regression test result for hypothesis 4 obtained $t_{\text {count }}$ of 0,273 and table of 1,684 with a significance level of 0.786 , which is greater than 0.05 . Based on the results of this study, H4 is rejected, which means that partially Spiritual Quotient variable does not significantly influence the auditor performance variable. Which also means that Spiritual Quotient does not affect auditor performance.

The Regression test result for hypothesis 5 obtained $t_{\text {count }}$ of 1,805 and table of 1,684 with a significance level of 0.038 , which means less than 0,05 . Based on the results of this study, $\mathrm{H}_{5}$ is accepted, which means that Emotional Quotient affect the relationship between Role Conflict and Auditor Performance. Emotional quotient has a communion with role conflict and Auditor Performance. Where with a high level of emotional skills an auditor is able to deal with the role conflict that is faced, so that it affects the performance of the auditor.

The Regression test result for hypothesis 6 obtained tount of 2,067 and table of 1,684 with a significance level of 0,047 which means less than 0,05 . Based on the results of this study, $\mathrm{H}_{6}$ is accepted, which means that Emotional Quotient affect the relationship between Role Ambiguity and Auditor Performance. Emotional quotient has a communion with role ambiguity and Auditor Performance. Where with an emotional skill an auditor is able to deal with the role conflict that is faced, so that it affects the performance of the auditor.

The Regression test result for hypothesis 7 obtained $t_{\text {count }}$ of 3,210 and tabel of 1,684 with a significance level of 0,017 which means less than 0,05 . Based on the results of this study, $\mathrm{H}_{7}$ is accepted, which means that Emotional Quotient affect the relationship between Self Efficacy and Auditor Performance. Emotional quotient has a communion with Self efficacy and Auditor Performance. Where with a high level of emotional skills an auditor will able to increasing their selfefficacy or confidence that can be seen from auditor's increasing performance.

Lastly, the Regression test result for hypothesis 8 obtained $t_{\text {count }}$ of 2,586 dan and $t_{\text {tabel }}$ of 1,684 with a significance level of 0,013 which means less than 0,05 . Based on the results of this study, $\mathrm{H}_{8}$ is accepted, which means that Emotional Quotient affect the relationship between Spritual Quotient and Auditor Performance. Emotional quotient has a communion with Spiritual quotient and Auditor Performance. Where with a high level of emotional skills an auditor will be reciprocal with the increase in spirituality and will improve the performance of an auditors in carrying out examinations.

\section{CONCLUSION, LIMITATIONS AND RECOMMENDATIONS}

Based on the research results above, from the results of this study, researchers can conclude that: role conflict, role ambiguity, self-efficacy affect the auditor performance. While spiritual quotient does not affect the auditor performance. And emotional quotient is a moderating variable for the relationship between auditor performance with role conflict, role ambiguity, self-efficacy, spiritual quotient.

For further research, it is necessary to add more independent variables and expand the research sample to see their effects on Auditor Performance. So, it can show how to create good performance for auditors. 


\section{REFERENCES}

Agustina, L. (2009). Pengaruh Konflik Peran, Ketidakjelasan Peran, dan Kelebihan Peran terhadap Kepuasan Kerja dan Kinerja Auditor (Penelitian pada Kantor Akuntan Publik yang Bermitra Dengan Kantor Akuntan Publik Big Four di Wilayah DKI Jakarta). Jurnal Akuntansi, 1 (1), 40-69.

Bandura, A. (1991). Self efficacy Mechanism in Psychological and Health Promotion Behavior. Prentice Hall. New Jersey.

Bandura, A. (1997). Self-Efficacy, The Exercise of Control. W.H. Freeman and Company, New York

Choiriah, A. (2013). Pengaruh Kecerdasan Emosional, Kecerdasan Intelektual, Kecerdasan Spiritual, dan Etika Profesi Terhaadap Kinerja Auditor dalam Kantor Akuntan Publik (Studi Empiris Pada Kantor Akuntan Publik di Kota Padang dan Pekanbaru. Thesis. Universitas Negeri Padang.

Fanani, Z., Hanif, R, A., \& Subroto, B. (2008). Pengaruh Struktur Audit, Konflik Peran, dan Ketidakjelasan Peran Terhadap Kinerja Auditor. Jurnal Akuntansi dan Keuangan Indonesia, 5 (2).

Goleman, D. (1999). Emotional Intelligence-Kecerdasan Emosional. Gramedia. Jakarta.

Ghozali, I. (2013). Aplikasi Analisis Multivariate dengan Program IBM SPSS 21 Update PLS Regresi. Semarang: Badan Penerbit Universitas Diponegoro.

Hanna, E., \& Firnanti, F. (2013). Faktor-faktor yang Mempengaruhi Kinerja Auditor. 15 (1). Universitas Diponegoro.

Kalbers, L. \& Fogarty, P.T. (1995). Professionalism and Its Consequences: A Study of Internal Auditors. Journal of Auditing, 14 (1), 64.

Kristiyanti, L.M.S. (2015). Pengaruh Emotional Quotient Dan Self- Efficacy Terhadap Kinerja Auditor (Studi Kasus Kantor Akuntan Di Surakarta Dan Yogyakarta. Jurnal Akuntansi dan Pajak.

Rosally, C., \& Jogi, Y. (2015). Pengaruh Konflik Peran, Ketidakjelasan Peran, Dan Komitmen Organisasi Terhadap Kinerja Auditor. Business Accounting Review, 3 (2).

Setiawan, T.H. (2018). Pengaruh Role Conflict, Role Ambiguity, Role Overload Terhadap Kinerja Akuntan Publik dengan Kecerdasan Spiritual Sebagai Pemoderasi. Universitas Syarif Hidayatullah Jakarta.

Wiguna, M. (2014). Pengaruh Role Conflict, Role Ambiguity, Self-Efficacy, Sensitifitas Etika Profesi, Gaya Kepemimpinan Terhadap Kinerja Audit. Jurnal Ilmiah Ekonomi dan Bisnis 11 (2), 503-519.

Yustiarti, et al. (2016). Pengaruh Konflik Peran, Ketidakjelasan Peran, dan Kelebihan Peran terhadap Kinerja Auditor dengan Kecerdasan Emosional sebagai Pemoderasi. Jurnal Akuntansi, 5 (1), 12-28.

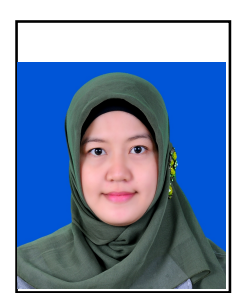

Meilda Wiguna was born in Sidinginan, Indonesia. Graduated with a Bachelor's degree in Accountancy from Economics and Business Faculty STIE YKPN in 2005. Continued her Master degree in Accountancy study program of the Faculty of Economics, University of Gadjah Mada (FE-UGM), graduated in 2010 and complete. Since 2010 he joined as a lecturer at Economics and Business Faculty Universitas Riau, Indonesia.

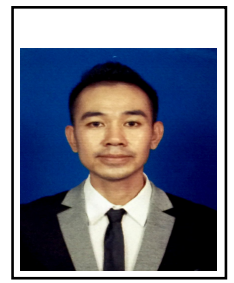

Khoirul Aswar was born in Sumatera Utara, Indonesia. Graduated with a Bachelor's degree in Accountancy from Economics and Business Faculty Janabadra University in 2008. Continued his Master degree in Accountancy study program of the Faculty of Economics, University of Gadjah Mada (FE-UGM), graduated in 2010 and complete. Doctorate degree in Accountancy in Universiti Utara Malaysia. Since 2011 he joined as a lecturer at Economics and Business Faculty Universitas Pembangunan Nasional Veteran Jakarta.

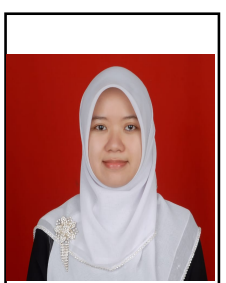

Eka Hariyani was born in Pekanbaru, Indonesia. Graduated with a Bachelor's degree in Accountancy from Economics and Business Faculty Universitas Riau in 2008. Continued her Master degree in Accountancy study program of the Faculty of Economics, Universitas Riau, graduated in 2014 and complete. Since 2008 she joined as a lecturer at Economics and Business Faculty Universitas Riau, Indonesia. 